\title{
Small Mammal Community of Forest Stands in Drahanská vrchovina Upland (Czech Republic)
}

\author{
*Ladislav Čepelka ${ }^{1}$; Luboš Purchart ${ }^{1}$; Josef Suchomel ${ }^{2}$ \\ ${ }^{1}$ Department of Forest Ecology, Mendel University in Brno, Faculty of Forestry and Wood Technology, Zemé- \\ dèlská 3, 61300 Brno, Czech Republic \\ ${ }^{2}$ Department of Zoology, Fisheries, Hydrobiology and Apiculture, Mendel University in Brno, Faculty of \\ Agronomy, Zemédélská 1, 61300 Brno, Czech Republic
}

\begin{abstract}
L., Purchart L., Suchomel J.: Small mammal community of forests stands in Drahanská vrchovina Upland (Czech Republic). - Beskydy, 8 (2): 91-100
\end{abstract}

\begin{abstract}
In the years 2006-2011 was studied community of small terrestrial mammals in the Drahanská vrchovina Upland. There were compared four stands of different age and tree species composition (30 years old spruce stand; 105 years old spruce forest; 125 years old mixed stand, and 40 years old beech stand). Totally 276 individuals of small terrestrial mammals were trapped and analyzed. The vast majority of cases were Apodemus flavicollis (163), Clethrionomys glareolus (81 specimen), and Apodemus sylvaticus (28). Besides previous species has been confirmed Sorex araneus (2) and Microtus arvalis (1). At all sites the most numerous species was A. flavicollis. Changes in species abundance were synchronized not only among themselves, but also in comparison to southern Moravia. The smallest amplitude and thus the smallest variation showed a population of mammals in old mixed forest. The highest population densities were found in younger spruce stand. The highest biodiversity according to all aspects except the number of species has been found among spruce stands.
\end{abstract}

Keywords: small mammals, Rodentia, Soricomorpha, diversity, forest ecosystems

\section{Introduction}

Monoculture stands of Norway spruce (Picea Abies) are generally considered the site unsuitable for small mammals. Especially it is considered true for younger stands. Those were found to be low in biodiversity, population density and productivity in terms of biomass (Zejda 1981). In this kind of environment does not usually occur any undergrowth. Moreover, spruces is seeding later and irregularly. The absence of undergrowth strongly limits the food resources for Arvicolidae rodents. Low reliable crops is limiting factor for the most obvious representative of small mammals in these conditions which are mice of genus Apodemus (Zejda 1981). Forests of the same climatic conditions with richer and more varied tree species composition, age and height structure usually maintain richer and more numerous community of small mammals (Gaisler and Šebela 1975; Pelikán et al. 1975; Anděra 1992; Suchomel 2007). Small terrestrial mammals populations of anthropogenic spruce monocultures in medium altitudes were studied only rarely (Zejda 1981; Kollars 1995; Suchomel et al. 2010). Numerous works dealed with communities of natural climax spruce forests in various stages of succession or wider synecological links (Zejda 1981; Gaisler 1983; Burger et al. 1987), eventually due to influence on trees (Gill 1992; Purchart and Suchomel 2007). A large part of the studies also focused on the role of Soricidae in mountain spruce forests and in Scandinavia (Kollars 1995; Shelftel and Hanski 2002).

The aim of the paper is a direct comparison of the basic ecological characteristics of small mammal communities in various types of managed forests in Drahanská vrchovina Upland. This should evaluate the influence and suitability of individual habitats for small mammals. The theme has been so far processed only partially (Suchomel et al. 2010). 


\section{Material And Methods}

\section{Study Area}

The study was carried out in the RájecNěmčice field research station and in research areas on the property of MP Lesy in the central part of the Drahanská vrchovina Upland. Field research station is about $3 \mathrm{~km}$ west of the village of Němčice (4929'31" N, 1643'30" E); other research areas are about $2.5 \mathrm{~km} \mathrm{~N}$ of the station. The area parent rock is acid granodiorite (Klimo and Maršálek 1999). The soil profile is created on diluvium layers of various thicknesses with disseminated granodiorite gravel and occasionally also boulders. The soil type is modal oligotrophic Cambisol (Menšík et al. 2009). The research plots are situated at an altitude between 600-660 $\mathrm{m}$ in moderately warm climatic region (Quitte 1971). Mean annual air temperatures is $6.5^{\circ} \mathrm{C}$; mean annual precipitation is $717 \mathrm{~mm}$ (Hadaš 2002). According to the Forest Management Institute qualification systematics (Plíva 1987), the potential vegetation forest type is Abieto-Fagetum with Oxalis (5S1) situated on the upper limit of the beech forest vegetation zone (Menšík et al. 2009).

There were selected four experimental plots (P1-P4) in the region (given age of the trees is at the beginning of the study, i.e. 2006):

P1-105 years old monoculture of Norway Spruce (Picea abies) underplanted at two spots (about 0.1 ha each) either by beech (Fagus sylvatica) or silver fir (Abies alba). On the spruce stand itself there was no undergrowth; on the spots there were Rubus sp., Calamagrostis sp., Avenella flexuosa and ferns.

P2 - 125 years old mixed stand (Picea abies, Fagus sylvatica, Abies alba). The plot undergrowth consists particularly of Rubus sp., Calamagrostis sp., Avenella flexuosa and intensive beech regeneration.

P3 - 30 years old Norway Spruce monoculture (Picea abies). It is a closed stand without undergrowth; poor undergrowth occurs on open places (such as road inside and at the edge of the stand - particularly Rubus sp., Calamagrostis sp., Avenella flexuosa).

P4 - 40 years old beech monoculture (Fagus sylvatica) with no herb layer.
P2 and P4 are isolated refugees surrounded by large spruce stands.

\section{Methods}

Small mammals were studied between 2006 and 2011. They were sampled twice a year in the spring (June) and autumn (October) by the snap traps (Pelikán 1975). The traps were laid in lines at 3-5 $\mathrm{m}$ spacing according to the stand density, namely 100 pcs (P1, P3, P4) and 80 pcs (P2). As a bait was used a kerosene lamp wick parched on oil and dusted with flour or a peanut butter. The traps were exposed for 4 days (i.e. 3 nights) and checked every following day. Trapped animals were dissected and identified to species according to standards (Zejda et al. 2002; Anděra and Horáček 2005).

The monitored communities were subject to evaluation of basic environmental characteristics, such as number of species (n), their relative abundance (rA) and dominance (D) (Losos et al. 1985). Diversity was assessed using the Shannon index H' based on the natural logarithm (Shannon and Weaver 1963), the Berger-Parker index (B) with the proportional dominance of the most abundant species, and finally the equitability index (E) (Sheldon 1969) expressing the evenness with which species are distributed (Magurran 2004). All calculations were processed by SW MS Excel 2007 and Statistica 10.

\section{Results}

\section{P1 - old norway spruce monoculture}

During the survey there was found 82 specimen of five small mammals. More than half of them were Apodemus flavicollis $(\mathrm{n}=43$; $\mathrm{D}=52.44 \%$ ). High was also representation of Clethrionomys glareolus ( $\mathrm{n}=27 ; \mathrm{D}=32.93 \%$ ) and Apodemus sylvaticus ( $\mathrm{n}=9$; $\mathrm{D}=10.98 \%$ ). In terms of the number of confirmed species this was the most interesting area. It was due to two individuals of Sorex araneus ( $\mathrm{n}=2, \mathrm{D}=2.44 \%$ ), and even a single ascertained specimen of Microtus arvalis $(\mathrm{n}=1 ; \mathrm{D}=22.1 \%)$. For the whole period was Shannon index in total $\mathrm{H}^{\prime}=1.09$, evenness $\mathrm{E}=$ 0.678 and the relative abundances of $\mathrm{rA}=2.28$. Changes in the relative abundance on the plot are on Fig. 1. 


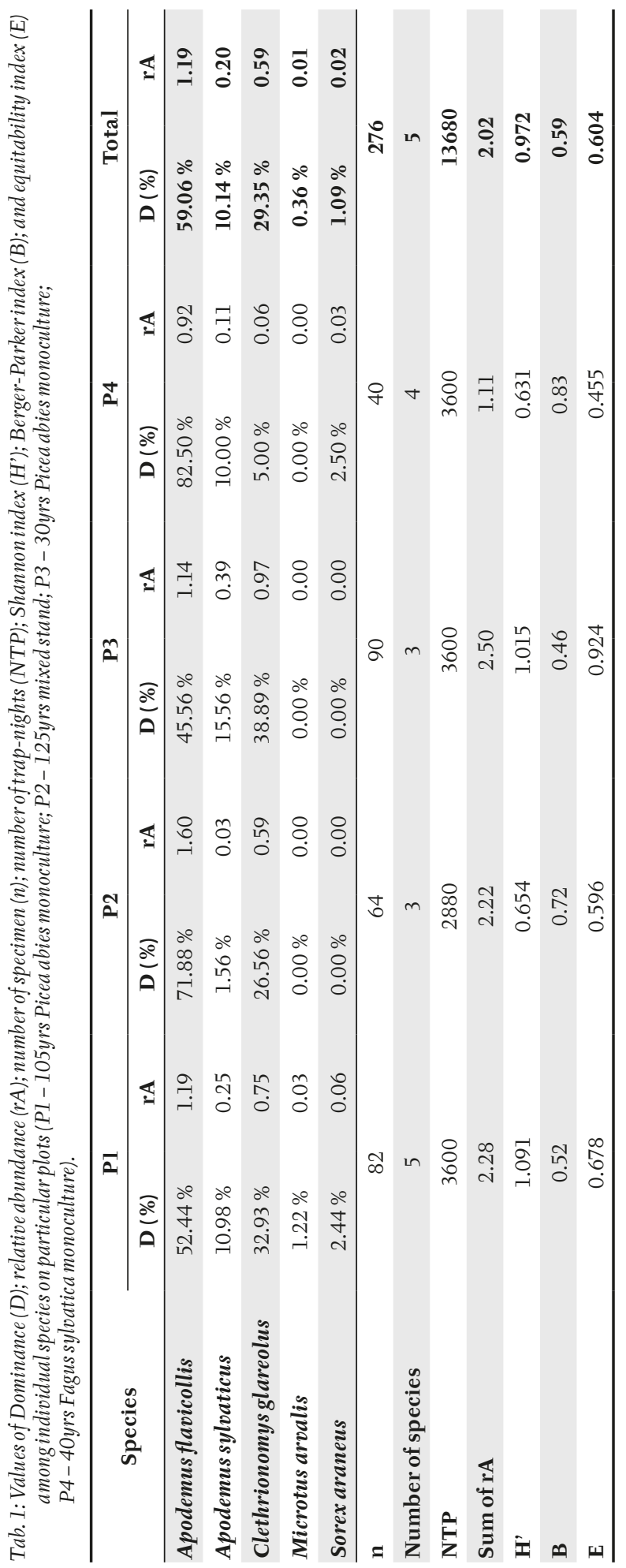




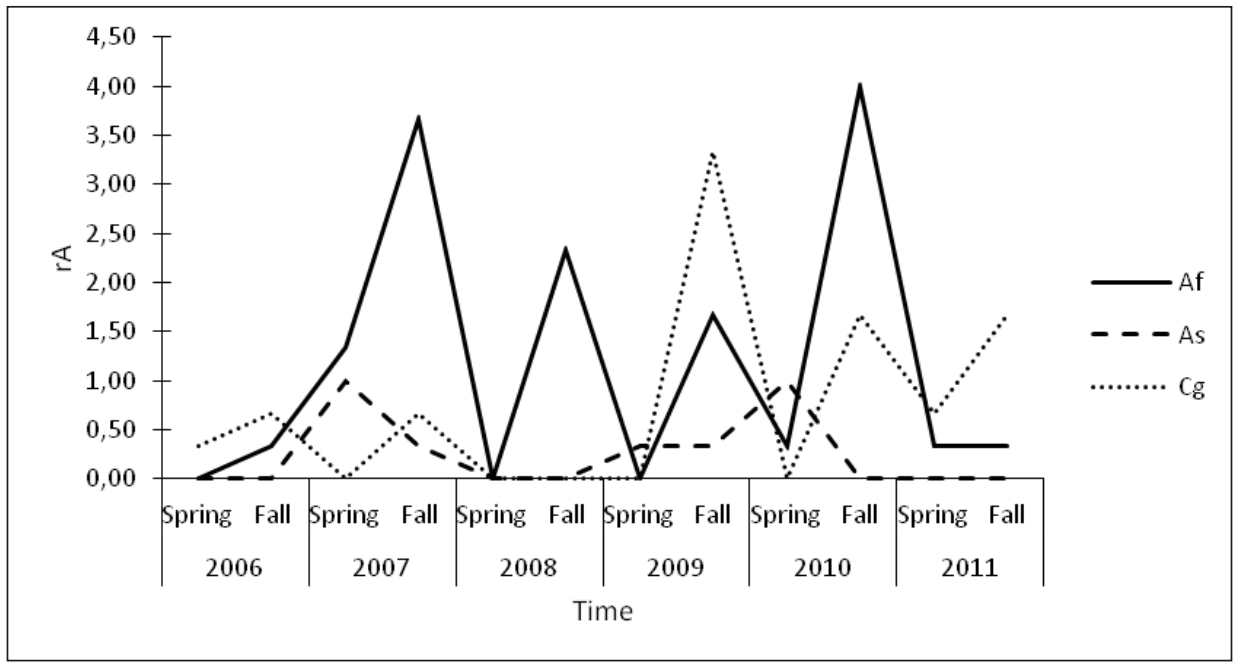

Fig. 1: Fluctuations of relative abundance ( $r A$ ) between 2006-2011 on plot P1 (105 years old Picea abies monoculture; Af-Apodemus flavicollis; As - Apodemus sylvaticus; Cg-Clethrionomys glareolus).

\section{P2 - old mixed stand}

Within the monitoring 64 individuals of three small mammal species was identified on the plot. Overwhelmingly the most numerous there was Apodemus flavicollis ( $\mathrm{n}=46 ; \mathrm{D}=71.88 \%$ ). Still high representation was at Clethrionomys glareolus ( $\mathrm{n}=17 ; \mathrm{D}=26.56 \%)$. The last species confirmed there was Apodemus sylvaticus ( $\mathrm{n}=1, \mathrm{D}=1.56 \%$ ). Shannon's index for the whole period was $\mathrm{H}^{\prime}=$ 0.654 , evenness $\mathrm{E}=0.596$, and the relative abundance $\mathrm{rA}=2.22$. Changes in the relative abundance on the plot are on Fig. 2.

\section{P3 - young Norway spruce monoculture}

During the entire monitoring 90 individuals of three small mammal species was identified on the plot. Predominance of Apodemus flavicollis here was the smallest ( $\mathrm{n}=41 ; \mathrm{D}=45.56 \%$ ), almost the same abundance was at Clethrionomys glareolus ( $\mathrm{n}=35 ; \mathrm{D}=38.89 \%)$. The last found species was Apodemus sylvaticus ( $\mathrm{n}=14 ; \mathrm{D}=15.56 \%$ ). Shannon's index there was H'= 1.015. The highest ever there was equitability $\mathrm{E}=0.924$ and the overall relative abundance $\mathrm{rA}=2.5$ Changes in the relative abundance on the plot are on Fig. 3.

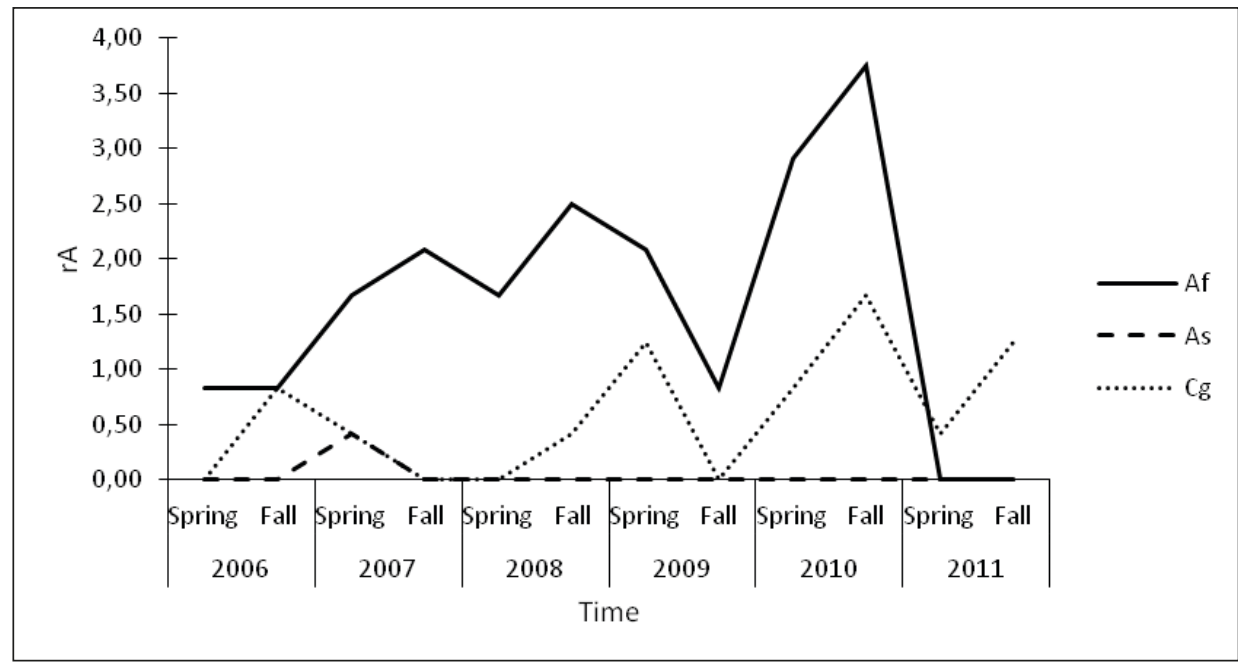

Fig. 2: Fluctuations of relative abundance ( $r A$ ) between $2006-2011$ on plot $\mathrm{P} 2$ (125 years old mixed stand; Af - Apodemus flavicollis; As - Apodemus sylvaticus; $\mathrm{Cg}$ - Clethrionomys glareolus). 


\section{P4 - young european beech monoculture}

Only 40 individuals of four small mammal species was identified on the plot during the monitoring. Superior was again Apodemus flavicollis $(\mathrm{n}=33 ; \mathrm{D}=82.5 \%)$. The remaining species were observed muchless - Apodemus sylvaticus $(\mathrm{n}=$ 4 by $\mathrm{D}=10 \%$ ) and Clethrionomys glareolus ( $\mathrm{n}=2$ by $\mathrm{D}=5 \%$ ). The last identified species was Sorex araneus $(\mathrm{n}=1$ by $\mathrm{D}=2.5 \%$ ). The local community reached the lowest value of the Shannon index $\left(\mathrm{H}^{\natural}=0.631\right)$, evenness $(\mathrm{E}=0.455)$ and significantly the relative abundances of $\mathrm{rA}=1.11$ among all studied plots. Changes in the relative abundance on the plot are on Fig. 4.

\section{Summary for all plots}

On all monitored plots in a given period 276 specimens of five small mammal species were caught. Four species were rodents (Rodentia), one representative insectivores (Eulipotyphla). By far the most numerous species was Apodemus flavicollis with total dominance of $59.06 \%$ ( $\mathrm{n}=163$ ). Significantly more represented were Clethrionomys glareolus $(\mathrm{D}=29.35 \% ; \mathrm{n}=81)$ and Apodemus sylvaticus ( $\mathrm{D}=10.14 \% ; \mathrm{n}=28)$. The rest two species have been represented only sporadically; Sorex araneus $(\mathrm{D}=1.09 \% ; \mathrm{n}=3)$ and Microtus arvalis $(\mathrm{D}=0.36 \% ; \mathrm{n}=1)$. Further details are in Tab. 1. Comparison of changes in relative abundance in all plots shows Fig. 5. The relative abundance of each species of mammals are in Fig. 6 to 9.

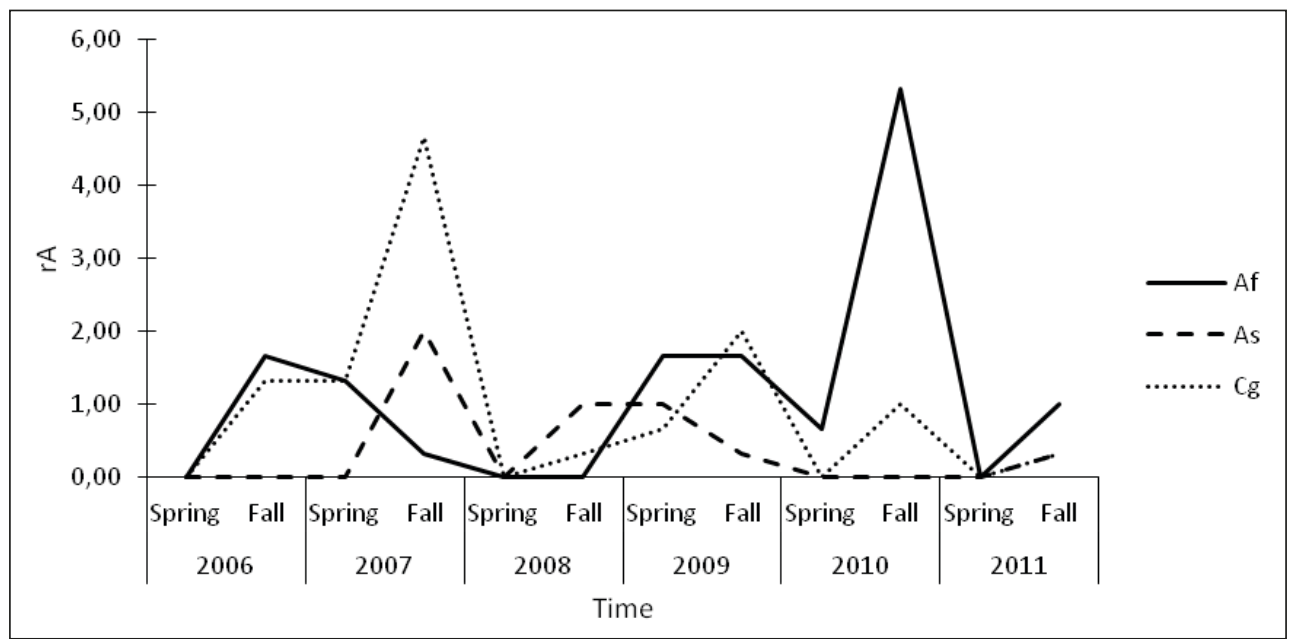

Fig. 3: Fluctuations of relative abundance (rA) between 2006-2011 on plot P3 (30 years old Picea abies monoculture; Af-Apodemus flavicollis; As-Apodemus sylvaticus; Cg-Clethrionomys glareolus).

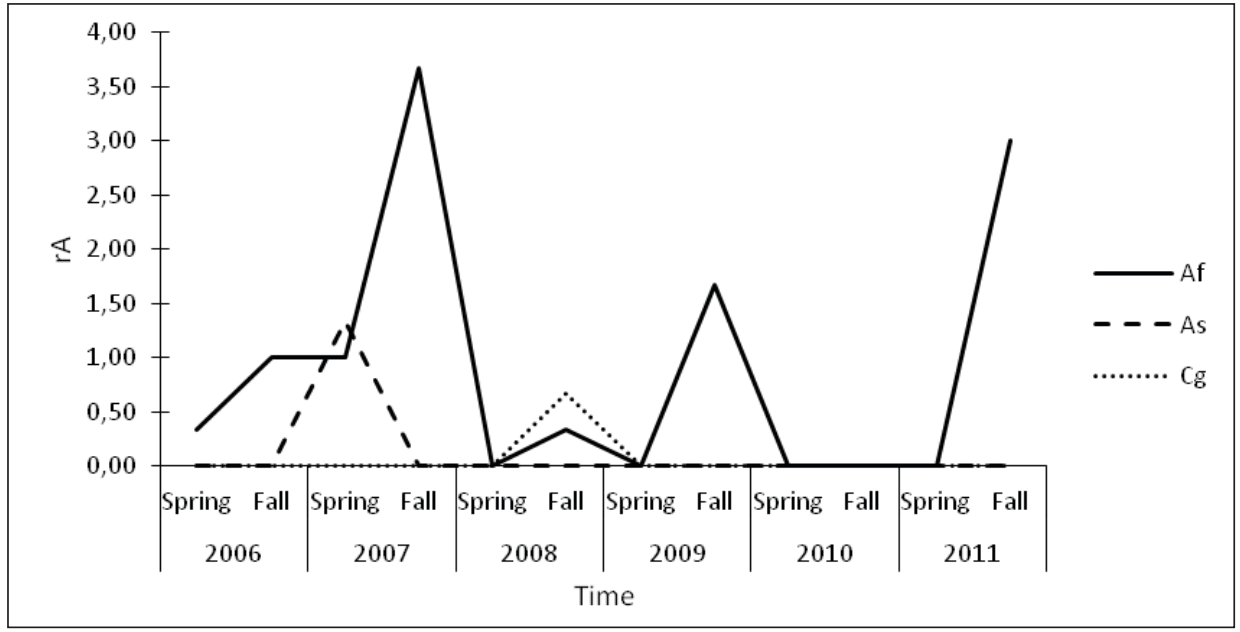

Fig. 4: Fluctuations of relative abundance (rA) between 2006-2011 on plot P4 (40 years old Fagus sylvatica monoculture; Af-Apodemus flavicollis; As-Apodemus sylvaticus; Cg-Clethrionomys glareolus). 


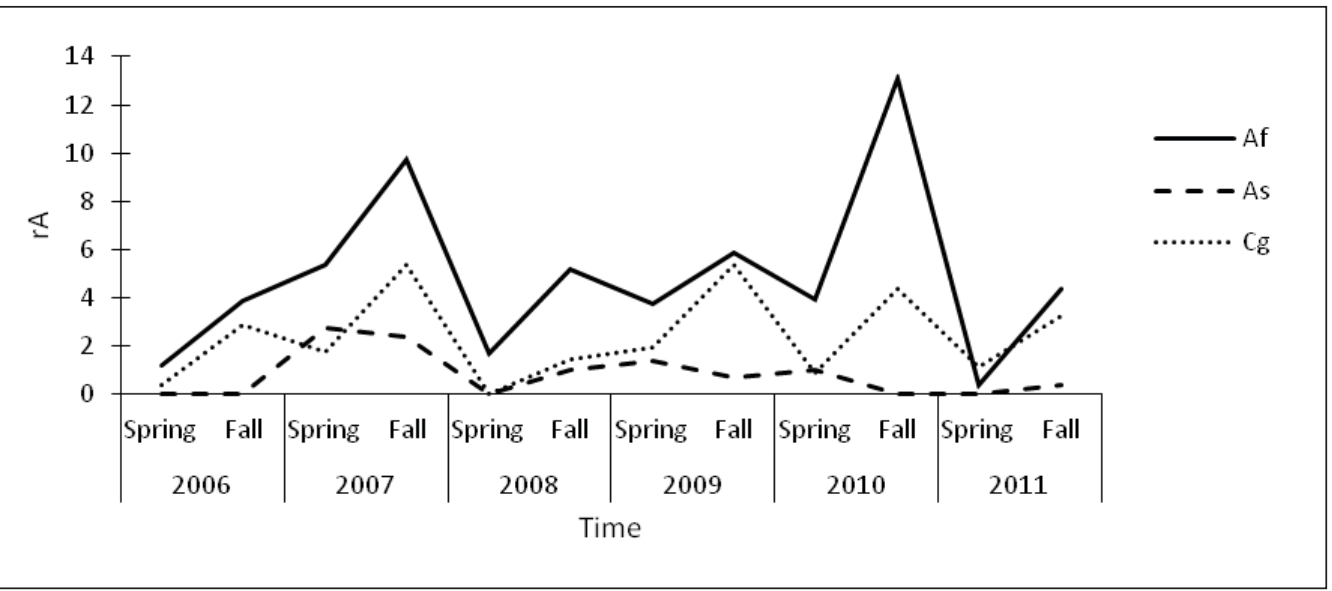

Fig. 5: Comparison of relative abundance ( $r$ A) fluctuations of small mammals between 2006-2011 on all plots together (Af-Apodemus flavicollis; As - Apodemus sylvaticus; Cg - Clethrionomys glareolus).

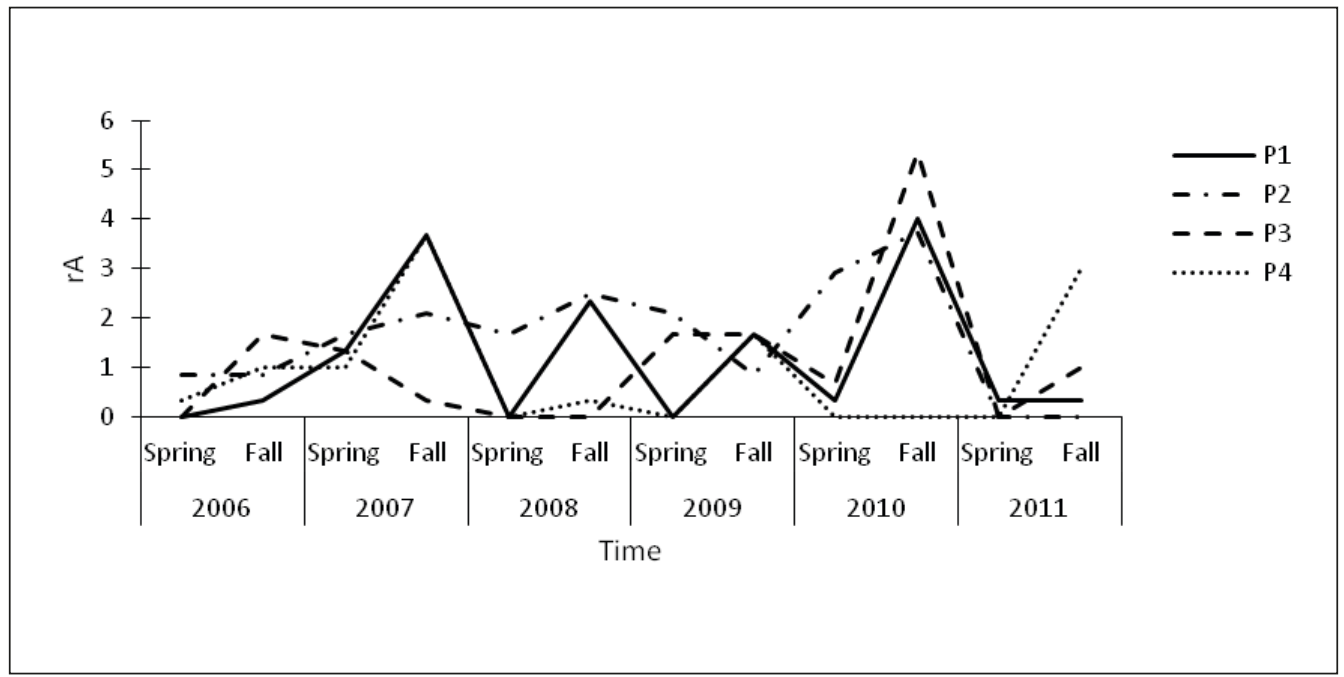

Fig. 6: Fluctuations of relative abundance (rA) of Apodemus flavicollis between 2006-2011 (P1 - 105yrs Picea abies monoculture; P2 - 125yrs mixed stand; P3 - 30yrs Picea abies monoculture; P4 - 40yrs Fagus sylvatica monoculture).

\section{Discussion}

Clearly the most abundant species during monitoring was Apodemus flavicollis (Tab. 1, Fig. $1-5)$. However, in more detail, it is clear that on each of the research plots was also the period when it was more caught Clethrionomys glareolus (Fig 1-4) and in some cases, A. sylvaticus (Fig. 1, 3 and 4). But since this happened on every plot in a different period, in aggregate (Fig. 5) A. flavicollis was the most abundant ever with the only exception of spring 2011. In a preliminary study (Suchomel et al. 2010) has been this species already more numerous than A. sylvaticus. However earlier study from the locality (Zejda
1981; Zejda et al. 2002) and other parts of Europe (Flowerdew et al. 1985; Selås et al. 2002) reported generally higher abundance of A. sylvaticus (about 30-40\%). This shift may be caused by long-term population cycles (Flowerdew et al. 1985) or by change of conditions in connection with the gradual increase in the representation of deciduous trees there (Klimo and Maršálek 1999). Abundance of A. flavicollis exceeded $70 \%$ in mixed and beech stands (P2 and P4; Tab. 1). This is significantly higher proportion than in spruce stands and as well higher value than was found elsewhere; either in the lowland (Zejda 1976; Suchomel and Heroldová 2004; Suchomel et al. 2012), in the highlands (Čermák 
and Ježek 2005; Suchomel 2007) and in mountains (Heroldová and Zejda 1995; Bryja et al. 1999; Bryja et al. 2001; Suchomel et al. 2007). A. flavicollis population probably bred in most of plots over the winter 2006/2007, which resulted in a gradation in the autumn of 2007. This was followed by a steep fall for minimum in 2008 (Fig. 5 and 6). Likewise, a fall to an absolute minimum (Spring 2011) followed the reaching of all-time highs (Autumn 2010), which is common (Flowerdew et al. 1985; Tkadlec and Zejda 1998; Tkadlec et al. 2006). We found large acorn crop in southern Moravia in 2006 and 2009, a bit lesser then in 2010 and 2011 (Čepelka et al. 2011). Gradation population of A. flavicollis on Drahanská vrchovina Upland is strongly synchronized to populations in southern Moravia. However, population densities in southern Moravia rose up to twice as high (Čepelka et al. 2011). A. flavicollis showed the most typical population curve in the mature spruce stand (P1; Fig. 1). The situation was similar in the case of a young spruce stand (P3). But, unlike on the other sites, there was a gradation in autumn 2006, and over the next two years, the population has declined (Fig. 3). Population in old mixed stand (P2) was the most stable, but as well the most unusual. It grown over the winters of 2006/7 and 2009/10. On the contrary from spring to autumn 2009 it significantly decreased. Therefore it is possible that a mixed forest, to a certain extent, dampens factors on other plots (Obrtel and Holišová 1974; Flowerdew et al. 1985).

Contrary to expectations, was Apodemus sylvaticus much less numerous (Zejda 1981; Zejda et al. 2002). It reached maximum population in the spring of 2007 (Fig. 5). It was also the only case where this species was found out of spruce forests (P1 and P3), which it otherwise clearly preferred (Fig. 7). The lowest representation of the species was in the mature mixed forest (P2), which is not usual for it (Zejda 1981; Flowerdew et al. 1985; Butet and Delettre 2011).

Preference of Clethrionomys glareolus were similarly to the previous species at the spruce stands (P1 and in particular P3). Unlike A. sylvaticus, C. glareolus was also represented in the mixed forest (P2). The population curve had standard course in spruce stands. Only in young spruce C. glareolus probably bred in the winter 2006/2007 (like almost all other species) and additionally also in the winter of 2008/2009. It almost did not occur in young beech (P4). This can probably be attributed to the total absence of undergrowth and therefore food opportunities (Hansson 2002) But especially difficult to explain is the situation in a mixed forest (P2). There was found no C. glareolus in autumn 2007 and spring 2008. Then it accrued over the winter of 2008/2009 and 2009/2010. In addition, in autumn 2009 it was not found. It is possible that in this case irregular predation plays the role (Hanski et al. 2001). Specifically, an area $\mathrm{P} 2$ could be affected by wild boar (Sus scrofa).

Significantly the lowest population densities of mammals according to the relative abundance were found in the beech $(\mathrm{P} 4 ; \mathrm{rA}=1.11)$. At all other plots, this value was at least twice higher (Tab. 1). Among the plots P1-P3 are the differences much smaller. The highest population density was found in young spruce (P3; rA $=2.5$ ). From this perspective both stands of adult trees are almost comparable. Surprisingly lower density was found in the mixed forest (P2, Fig. 1).

The highest number of species was in old spruce (P1; 5 species) and young beech (P4; 4 species). Shannon diversity index (H') was relatively low $\left(\mathrm{H}^{\prime}=0.6-1\right)$. This corresponds to the preliminary results (Suchomel et al. 2010) while across the most of the Czech Republic these values were higher (Bryja et al. 2001; Suchomel and Heroldová 2004; Čermák and Ježek 2005; Suchomel 2007). Only in the floodplain forest the Shannon index was more or less the same (Zejda 1976). The best from the point of view of biodiversity indexes were both of the spruce forest, less old mixed stand and the last was young beech (Tab. 1). Both spruce plots ( $\mathrm{Pl}$ and P3) showed as well higher diversity according to the Berger-Parker index and equitability index.

\section{Conclusion}

Small mammal community at Drahanská vrchovina Upland was relatively poor with low population densities. At all sites the most numerous species were Apodemus flavicollis, also significantly represented were Clethrionomys glareolus and Apodemus sylvaticus. Only marginally there were Sorex araneus and Microtus arvalis. Changes in species abundance were synchronized with one another, but also in comparison with southern Moravia (and the local crop of acorns). The smallest amplitude and thus the smallest variation showed a population of mammals in old mixed forest. The highest population densities were found in young spruce. The highest biodiversity according to all aspects except the number of species was found in spruce stands.

\section{Acknowledgement}

The paper was supported by financial means of the MSM 6215648902 and NAZV 72075 projects. 


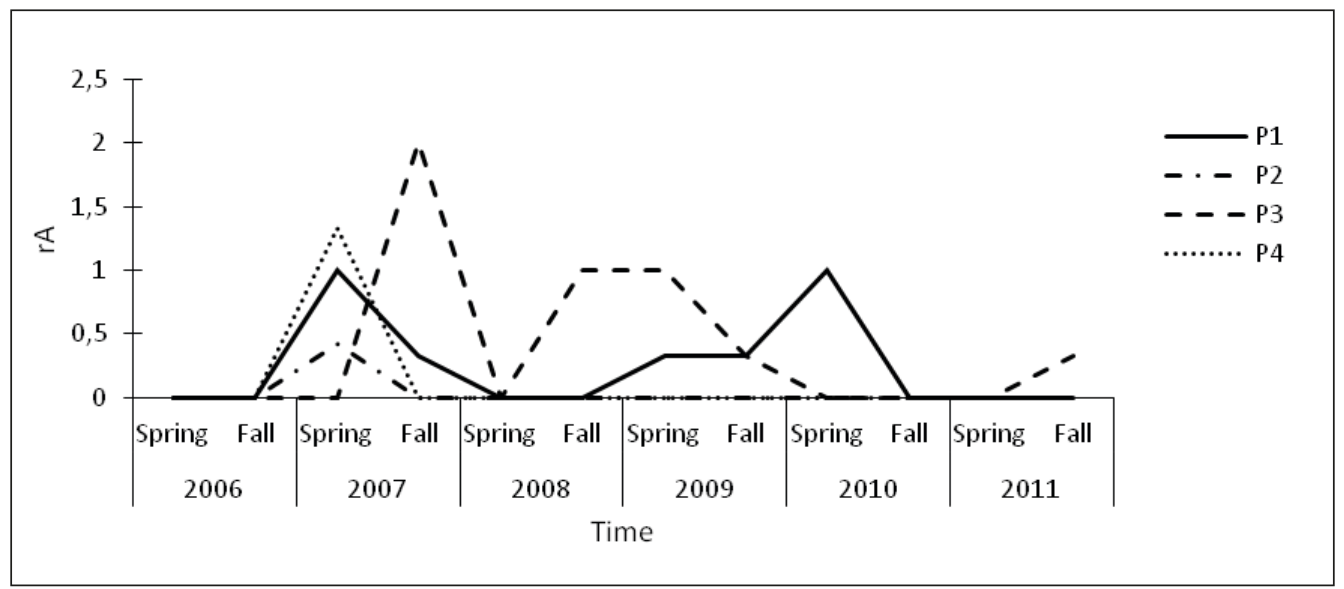

Fig. 7: Fluctuations of relative abundance (rA) of Apodemus sylvaticus between 2006-2011 (P1 - 105yrs Picea abies monoculture; P2 - 125 yrs mixed stand; P3 - 30yrs Picea abies monoculture; P4 - 40yrs Fagus sylvatica monoculture).

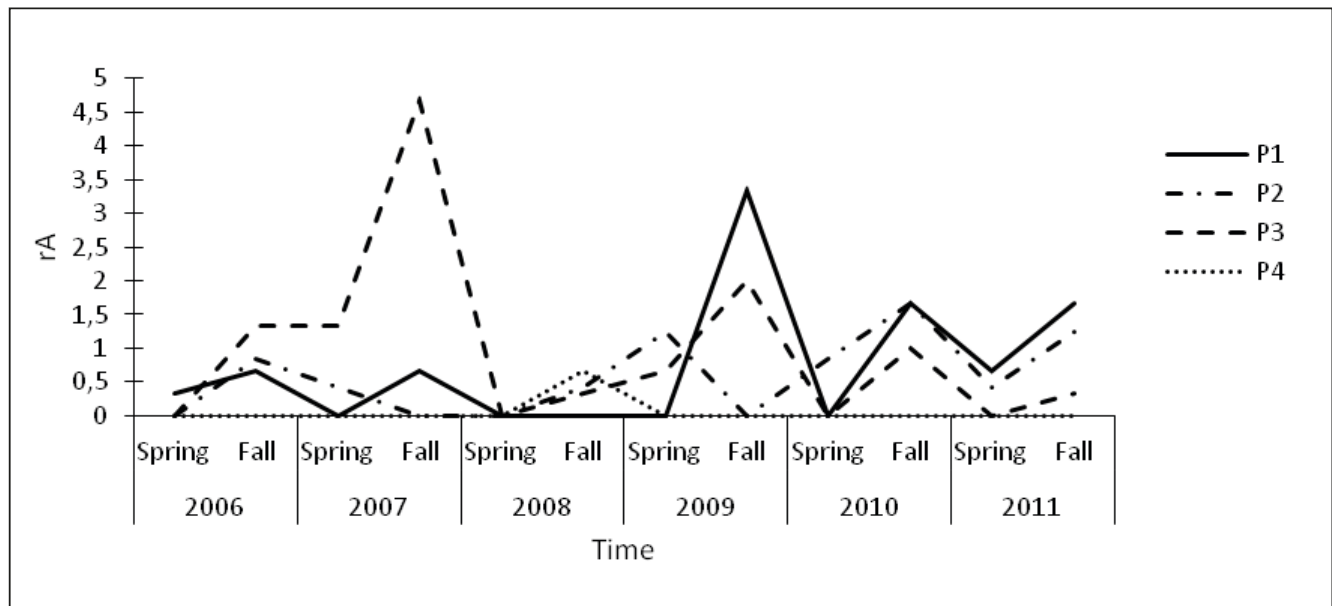

Fig. 8: Fluctuations of relative abundance (rA) of Clethrionomys glareolus between 2006-2011 (P1 - $105 y$ rs Picea abies monoculture; P2 - 125 yrs mixed stand; P3 - 30yrs Picea abies monoculture; P4 - 40yrs Fagus sylvatica monoculture).

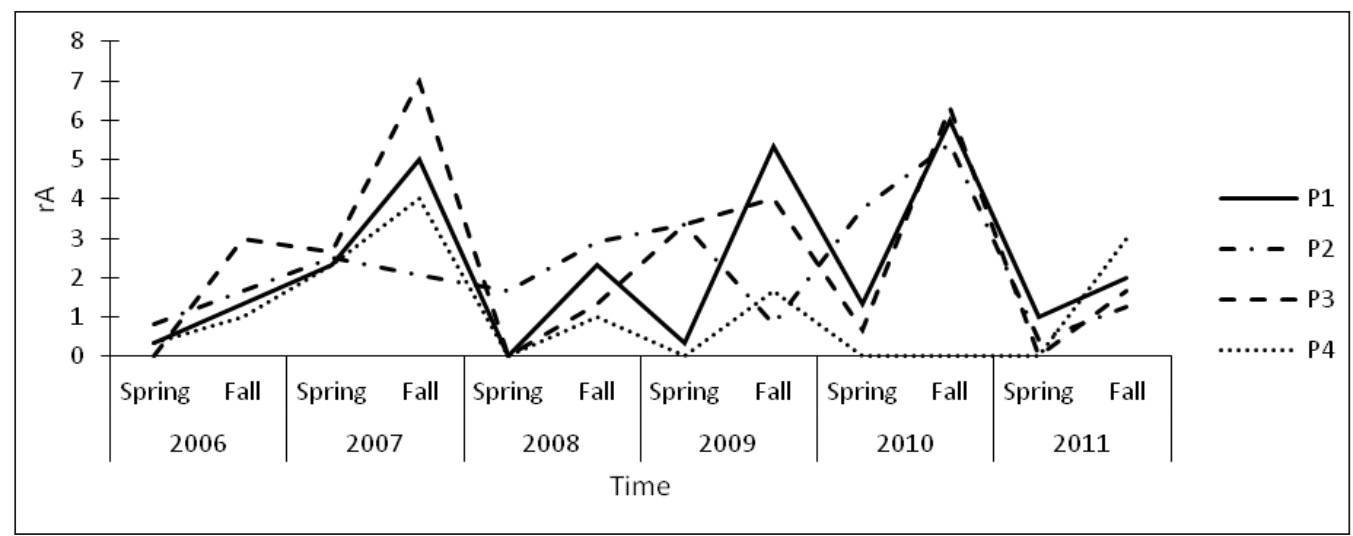

Fig. 9: Fluctuations of relative abundance (rA) of small mammals between 2006-2011 (P1 - 105yrs Picea abies monoculture; P2 - 125yrs mixed stand; P3 - 30yrs Picea abies monoculture; P4 - 40yrs Fagus sylvatica monoculture). 


\section{References}

ANDĚRA, M. 1992: The small mammal community of the Hercynian mountain beech and fir forest (Šumava Mts.). Acta Soc. Zool. Bohemoslovakiae, 56: 81-91.

Anděra, M., HorÁčEK I. 2005: Poznáváme naše savce. 2. přepracované vydání. Sobotales, Jihlava, 327 pp.

Bryja, J., Heroldová, M., Zejda, J. 2001: Společenstva drobných savců ve vrcholových partiích Beskyd. Beskydy, 14: 201-208.

Bryja, J., Šugerková, M., Heroldová, M. 1999: Drobní zemní savci (Insectivora, Rodentia) nadregionálního biocentra Kněhyně - Čertův mlýn (předběžné výsledky). Zpravodaj Beskydy, 12:151-156.

Burger, P., ANDĚrA, M., ZBYtKovskÝ, P. 1987: Savci Blanského lesa (Šumavské podhůří). Lynx (Praha), n.s. 23: 5-42.

Butet, A., Delettre, Y.R. 2011: Diet differentiation between European arvicoline and murine rodents. Acta Theriol. (Warsz), 56: 297-304.

Č́epelka, L., Heroldová, M., Purchart, L., SuCHOMEL, J. 2011: Závislost populační dynamiky myšice lesní (Apodemus flavicollis) a norníka rudého (Myodes glareolus) na úrodě žaludu na jižní Moravě. In: Zoologické dny 2011: p. 282.

ČERMÁK, P., JEŽEK, J. 2005: Effect of tree seed crop on small mammal populations and communities in oak and beech forests in the Drahany Upland (Czech Republic). J. For. Sci. 51: 6-14.

Flowerdew, J.R., GuRnell, J., GIPPS, J.H.W. 1985: The ecology of woodland rodents bank voles and wood mice. In: Symposia of the Zoological Society of London, 89-115.

GAISLER, J. 1983: The community of rodents and insectivores on the ridge of the Orlické hory Mts. In the ten years aspect. Folia Zool., 32: 241-257.

Gaisler, J., Šebela, M. 1975: Abundance, diversity and production of small mammals (Rodentia, Insectivora) in two diff erent forest ecosystems. Scr.fac. Sci. Nat. UJEP Brun Biol., 25: 99-114.

GILL, R. M.A. 1992: A review of damage by mammals in North temperate forests. 3. Deer. Forestry, 65: 145-169.

HADAš, P. 2002: Temperature and precipitation condition in the high elevation spruce stands of the Drahanská vrchovina Upland. Ekol., 21: 69-87.

Hanski, I., Henttonen, H., Korpimäki, E. et AL. 2001: Small-rodent dynamics and predation. Ecology, 82: 1505-1520.

Hansson, L. 2002: Dynamics and trophic interactions of small rodents: landscape or regional effects on spatial variation? Oecologia, 130: 259-266.
HeroldovÁ, M.,ZejdA, J. 1995: Výsledky výzkumu společenstva drobných zemních savců v oblasti Beskyd s ohledem na poškozování lesních porostů imisemi. Zpravodaj Beskydy, 7: 153-156.

KLIMO, E., MARŠÁLEK, J. 1999: Manmade Spruce Ecosystem (Structure, Function, Production, Processes). Report from Project Rajec, 178 pp.

Kollars, T.M. 1995: Home range and population densities of shrews (Soricidae) inhabiting a spruce plantation in Bavaria, Germany. Acta Theriol. (Warsz), 40: 219-222.

Losos, B., GuličKa, J., Lellak, J., Pelikán, J. 1985: Ekologie živočichü. SPN, Prague, 320 pp.

MagurRan, A.E. 2004: Measuring Biological Diversity. Blackwell Science, Oxford, $215 \mathrm{pp}$.

Menší, L., Fabiánek, T., Tesař, V., Kulhavý, J. 2009: Humus conditions and stand characteristics of artificially established young stands in the process of the transformation of spruce monocultures. J. For. Sci. 55: 215-223.

Obrtel, R., Holišová, V. 1974: Povaha potravy Apodemus flavicollis a Clethrionomys glareolus v lužním lese. Lynx, 16: 37-45.

PELIKÁN, J. 1975: K ujednocení odchytového kvadrátu a linie pro zjištování populační hustoty savců v lesích. Lynx, n.s., 17: 58-71.

Pelikán, J., Zejda, J., Holišová, V. 1975: Influence of trap spacing on the catch size of dominant species of small forest mammals. Zool. Listy, 24: 313-324.

Plíva, K. 1987: Typologický klasifikační systém ÚHÚL. ÚHÚL, Brandýs nad Labem, 52 pp.

Purchart, L., Suchomel, J. 2007: The impact of small terrestrial mammals on beech (Fagus sylvatica) plantations in spruce monoculture. Beskydy, 5: 131-136.

QuitTE, E. 1971: Klimatické oblasti Československa. Geografický ústav ČSAV, Brno, 73 pp.

Selås, V., Framstad, E., Spidsoe, T.K. 2002: Effects of seed masting of bilberry, oak and spruce on sympatric populations of bank vole (Clethrionomys glareolus) and wood mouse (Apodemus sylvaticus) in southern Norway. J. Zool., 258: 459-468.

Shannon, C.E., Weaver, W. 1963: The Mathematical Theory of Communication. Urbana: Univ. Illinois Press, 144 pp.

Sheldon, A.L. 1969: Equitability indices: Dependence on the species count. Ecology, 50: 466-467.

SHELFTEL, B.I., HANSKI, I. 2002: Species richness, relative abundances and habitat use in local assemblages of Sorex shrews in Eurasian boreal forests. Acta Theriol. (Warsz), 47: 69-79. 
Suchomel, J. 2007: A study of the synusia of small terrestrial mammals (Insectivora, Rodentia) of the Kelečská pahorkatina Upland - Czech Republic. Acta Univ. Agric. Silvic. Mendelianae Brun, LV: 165-170.

Suchomel, J., HeroldovÁ, M. 2004: Small terrestrial mammals in two types of forest complexes in intensively managed landscape of South Moravia (The Czech Republic). Ekol., 23: 377-384.

Suchomel, J., Heroldová, M., Purchart, L. 2007: The study of changes in the synusia of small terrestrial mammals (Insectivora, Rodentia) of top parts of the Beskids (preliminary results). Beskids Bulletin, 20: 211-216.

Suchomel, J., Purchart, L., Urban, J. 2010: Spruce monocultures of the Drahanská vrchovina upland (Czech Republic) as the biotope of small terrestrial mammals (Rodentia, Soricomorpha). Acta Univ. Agric. Silvic. Mendelianae Brun., LVIII: 185-194.

Tkadlec, E., ZвoŘil, J., Losík, J., Gregor, P., LiSICKÁ, L. 2006: Winter climate and plant productivity predict abundances of small herbivores in central Europe. Clim Res 32: 99-108.

TKadLEe, E., ZejDA, J. 1998: Small rodent population fluctuations: The effects of age structure and seasonality. Evol. Ecol., 12: 191-210.

ZEJDA, J. 1981: The small mammal community of a spruce monoculture. Acta Sci. Nat. Brno 15: 1-31.

ZEJDA, J. 1976: The small mammal community of a lowland forest. Acta Sci. Nat. Brno, 10: 1-39.

Zejda, J., Zapletal, M., Pikula, J., ObdržÁlková, D., Heroldová, M., Hubálek, Z. 2002: Hlodavci $v$ zemédélské a lesnické praxi. Agrospoj, Prague, $284 \mathrm{pp}$. 